\title{
Effect of the Puyehue-Cordon Caulle volcanic complex eruption on crustacean zooplankton of Andean lakes
}

\author{
Esteban Balseiro ${ }^{\varpi}$; María S. Souza; Ignacio Serra Olabuenaga; Laura Wolinski; \\ Marcela Bastidas Navarro; Cecilia Laspoumaderes \& Beatriz Modenutti \\ Laboratorio de Limnología, INIBIOMA (CONICET-Universidad Nacional del Comahue). Centro Regional Universitario \\ Bariloche. Bariloche, Argentina.
}

\begin{abstract}
Aвstract. We studied the effect of volcanic ash on the crustacean zooplankton (mainly cladocerans) in the Andean North-Patagonian lakes that were affected by the eruption of the Puyehue-Cordón Caulle complex. The study was carried out at three different scales: sub cellular, population and ecosystemic. Cladocerans are filter feeding organisms that cannot distinguish between food (algae less than $30 \mu \mathrm{m}$ ) and suspended ash, therefore when feeding they ingest this material. The ash affected negatively the individuals at a biochemical level, increasing the oxidative stress reacting enzymes like Glutation-S-transferase and the biomarker Acetyl cholinesterase. At the population level, we recorded a decrease in survival and fecundity, in particular, when ash concentration exceeded $8 \mathrm{mg} / \mathrm{L}$, we observed that individuals did not reach adulthood. At the ecosystem level, we recorded a significant decrease of the intermediate trophic level (primary consumers) although producers were positively enhanced by the eruption. The absence of these primary consumers may affect upper trophic levels like fishes. Later, in the year following the eruption, we observed the resurgence of zooplankton populations suggesting a fast recovery from the initial conditions.
\end{abstract}

[Keywords: volcanic ash, cladocerans, oxidative stress, survivorship, trophic level]

Resumen: Efecto de la erupción del Complejo Volcánico Puyehue-Cordón Caulle en el zooplancton crustáceo de los lagos andinos: En este trabajo analizamos el efecto de las cenizas en el zooplancton crustáceo (cladóceros en particular) de lagos andinos norpatagónicos afectados por la erupción volcánica del Complejo PuyehueCordón Caulle. Los estudios se llevaron a cabo en tres escalas diferentes, subcelular, poblacional y ecosistémica. Los cladóceros son organismos filtradores que no pueden discriminar eficientemente entre el alimento (algas de tamaño menor a $30 \mu \mathrm{m}$ ) y la presencia de cenizas, por lo cual éstas son ingeridas. Las cenizas en suspensión impactaron negativamente en los individuos a nivel bioquímico incrementando el estrés oxidativo, provocando cambios en enzimas como la Catalasa y Glutatión-S-transferasa así como en el biomarcador Acetilcolinesterasa. A nivel poblacional se registró una disminución en la supervivencia y en la fecundidad con concentraciones crecientes de cenizas. En particular con valores de concentración de cenizas superiores a los $8 \mathrm{mg} / \mathrm{L}$ se observó que los individuos no llegaban a la edad de primera reproducción. A escala ecosistémica se verifica una disminución significativa del nivel trófico intermedio de consumidores primarios a pesar del incremento del nivel de los productores. La ausencia de este nivel trófico podría redundar en cambios en niveles tróficos superiores como los peces. Por último, la recuperación de las poblaciones del zooplancton fue verificada al año subsiguiente de la erupción, lo que sugirie una restauración rápida de las condiciones originales.

[Palabras clave: cenizas volcánicas, cladóceros, estrés oxidativo, supervivencia, nivel trófico]

\section{INTRODUCTION}

Volcanic eruptions affect ecosystems at local, regional and even global scales due to ejection and emission of gases, ash, pumice and lava. Although most ecological changes are gradual, extensive changes in ecosystems can sometimes occur over short periods of time (Holling 1973; Scheffer \& Carpenter 2003; Walker \& Meyers 2004). In that sense, volcanic eruptions are sudden processes that can affect substantially the landscape and climate. Thus, volcanic eruptions present good opportunities for scientific discovery allowing the comprehensive assessment of their effects and the mechanisms

Editor invitado: Thomas Kitzberger of those outcomes (Lindenmayer et al. 2010; Larson 2011).

Because of the large number of active volcanoes in Chile, and the prevailing winds from the W-NW a large part of the Argentinean territory is frequently affected by the explosive plumes (Villarosa et al. 2006; Durant et al. 2012). In particular, the Puyehue-Cordón Caulle volcanic complex $\left(40^{\circ} 30^{\prime} \mathrm{S}, 72^{\circ} 07^{\prime} \mathrm{W}\right.$, Chile) has become much more explosive over time (Singer et al. 2008), with the last eruption starting on June $4^{\text {th }}, 2011$. This volcanic event expelled pumice and ash to the atmosphere during a relatively long period 
of time (June 2011 through March 2012). Ash particles dispersed over a large part of the Argentinean territory and the ash cloud even circled the globe in the Southern Hemisphere (Klüser et al. 2013).

The consequences of this input of material to the aquatic environments varied according to the size of the particles. The largest fraction of the pumice had a porous structure, and hence low density, and therefore remained floating on the water surface until it is broken down to smaller pieces and is finally deposited on the shore or in the bottom of the lakes. The fine fraction is essentially vitreous with sharp edges and conchoidal fracture (Buteler et al. 2011; Caneiro et al. 2011) and remained suspended in the water column for long periods of time interfering with physical and biological processes (Modenutti et al. 2013a). In particular, data obtained from Andean North-Patagonian lakes affected by the Puyehue-Cordón Caulle volcanic eruption (Figure 1) showed a particle size distribution with a mode lower than $2.5 \mu \mathrm{m}$ (Modenutti et al. 2013a, 2013b). However, in aquatic systems, the effects are not just limited to the transient ash fall, but also often persist for several months due to the resuspension of the ash by the movements of the water column (Inbar et al. 1995; Horwell et al. 2003).

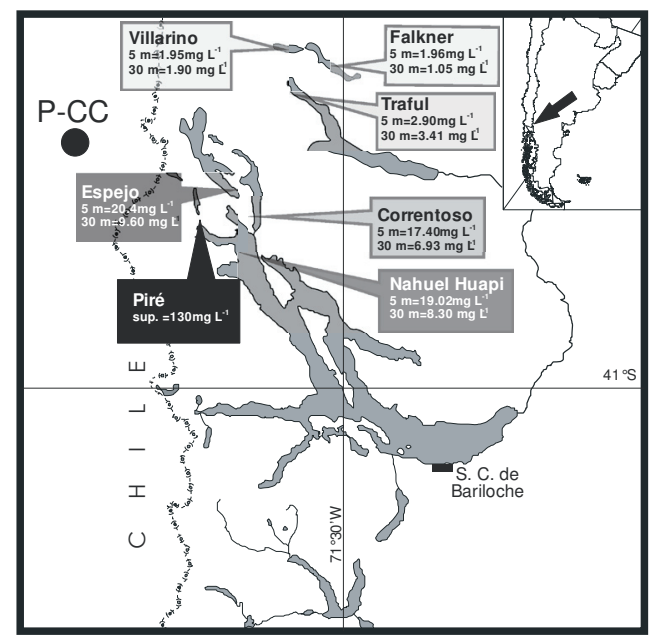

Figure 1. Map of the lakes near Puyehue-Cordón Caulle Complex that were affected by the eruption, showing the concentration of suspended ash at $5 \mathrm{~m}$ and $30 \mathrm{~m}$ depth, except for lake Pire which is a shallow lake so the deep value is not presented. P-CC indicates the location of the volcano.

Figura 1. Mapa de los lagos cercanos al Complejo PuyehueCordón Caulle afectados por la erupción con los valores de la concentración cenizas volcánicas en suspensión a $5 \mathrm{~m} \mathrm{y}$ a $30 \mathrm{~m}$ de profundidad excepto en laguna Piré en donde el valor de profundidad no se presenta por ser un sistema somero. P-CC indica la ubicación del volcán.
The main components of volcanic ash are silicate, and crystalline phases as quartz, feldspar, plagioclase, pyroxene, olivine, iron, and finally some iron and titanium oxides are also frequent in different proportions (Tarbuck et al. 1999). Accordingly, the major components of the ash from the PuyehueCordón Caulle eruption were $\mathrm{O}, \mathrm{Si}, \mathrm{Al}, \mathrm{Fe}, \mathrm{Na}$ and K (Buteler et al. 2011; Caneiro et al. 2011). Immediately after the eruption and due to the input of ash, the total suspended solid (TSS) concentration increased notably in the affected lakes (Figure 1), however conductivity and $\mathrm{pH}$ did not vary between pre and post eruption data (Wolinski et al. 2013). The observed increase in TSS due to volcanic ash caused changes in light availability, nutrient inputs and phytoplankton (Modenutti et al. 2013a). Concurrently, cladocerans were also affected by suspended ash particles, which were within the range of their food spectrum, and therefore could be ingested by filter-feeding zooplankton (Wolinski et al. 2013).

The aim of the present work was to synthesize the effects of ash on the crustacean zooplankton in Andean North-Patagonian lakes, combining the results of previous studies in three different scales: sub cellular, population and ecosystem levels. For this purpose, we here reanalyze previous work on the zooplankton of Andean North-Patagonian lakes (Modenutti et al. 2010 and references therein) examining the impact both at the biochemical (Serra-Olabuenaga 2013) and the population level (Wolinski et al. 2013). Finally, we analyze the effect at the ecosystem level of the pelagic food web based on Wolinski et al. (2013) and Modenutti et al. (2013a, 2013b).

\section{ZOOPLANKTON}

The zooplankton plays an important role in the transfer of carbon in the food webs (Carpenter et al. 2001), with a key position connecting the lower trophic levels (algae and bacteria) with the higher trophic levels (fishes). Therefore, zooplankton feeding constitutes the main pathway for the mass and energy fluxes in lacustrine systems (McQueen et al. 1989). In consequence, any change at this level may cause changes up and down the food web (Carpenter et al. 1988; Faithfull et al. 2011). On the other hand, the water quality is the result of external impacts on ecosystems together with internal transformations through complex interactions, where the zooplankton plays a fundamental role (Carpenter et al. 1996). 
Herbivorous zooplankton feeds mainly by filtering particles smaller than $50 \mu \mathrm{m}$ (especially smaller than $30 \mu \mathrm{m}$ ) (Sterner 1989; Balseiro et al. 2001). Particle removal by zooplankton is a process that can involve different feeding strategies including filtering the whole suspended stock, particle selection through mechanoreceptors or other specialized structures, that are mainly explained by the anatomical structure of the different zooplankton components (i.e., rotifers, cladocerans and copepods) (DeMott 1989). For example, daphnids cladoceran feed non-selectively across a wide range of food types and sizes including various mixtures of algae and inorganic particles, such as clay (Gliwicz 1986a) and flavored and untreated microspheres (DeMott 1982, 1986), while other zooplankton, such as copepods, are more selective on motile cells (Balseiro et al. 2001). For daphnids the size range of edible particles is determined by the carapace opening (maximum size) and the appendix intersetular distance (minimum size) (Lampert 1987). Thus, daphnids can exert a significant grazing pressure on different components of micro- and nanophytoplankton assemblages (1-30 m) (Geller \& Müller 1981; Jürgens 1994).

Cladocerans are considered key organisms in aquatic ecosystems because they connect upper trophic levels with lower ones (McQueen et al. 1989). Cladoceran survival and development are influenced by many factors of their natural environments, such as predation (Gliwicz 1986b; Vanni 1987), food quality (Lynch 1989; Boersma \& Vijverberg 1996; Brett et al. 2000), and ultraviolet radiation (Siebeck et al. 1994). Early studies indicated that the ingest of particles, such as suspended clay, during feeding can reduce fecundity and survival in daphnids (McCabe \& O'Brien 1983; Kirk \& Gilbert 1990). Volcanic particles are very similar in size to glacier clay (Modenutti et al. 2013b), therefore it can be expected that filter feeders would ingest ash as they did with clay. Hence, the appearance of the volcanic ash particles in the lakes after the eruption might cause a decrease in cladoceran populations with consequences in the whole food web.

The zooplankton assemblage of the NorthPatagonian Andean lakes is rather simple and composed by very few and small species (Modenutti et al. 2010). Zooplankton is dominated by calanoid copepods of the Family
Centropagidae, in particular by Boeckella gracilipes (less than $1 \mathrm{~mm}$ in length) (Balseiro et al. 2001). This copepod has an omnivorous diet preying on motile cells like nanoflagellates and ciliates (Balseiro et al. 2001). Among cladocerans, most of the lakes have daphnids, as Ceriodaphnia dubia, while some of these lakes can be inhabited by Daphnia (D. commutata) (Balseiro et al. 2007, 2008). These daphnids are non-selective filter feeders filtering particles of less than $20 \mu \mathrm{m}$ in diameter (Matveev \& Balseiro 1990; Balseiro \& Modenutti 1990; Balseiro et al. 2007). Considering the feeding features of the crustacean zooplankton we choose cladoceran daphnids, in particular $D$. commutata a species that we have in laboratory cultures, as sensitive organisms to test the input of volcanic ash into lakes.

\section{Sub CELlular SCALE}

Zooplankton, as all oxygen-consuming organisms generate large amounts of reactive oxygen species (ROS). These species are normal by-products of oxidative metabolism, though under stress an increase of ROS production can cause a potential threat to cell metabolism (Kim et al. 2009). ROS are highly reactive compounds that can react with different macromolecules (i.e., lipids, DNA, proteins) generating secondary organic ROS in an amplification cascade. Oxidation of biomolecules may alter cellular and tissue function (Barata et al. 2005). Hence, the organisms have developed a wide range of defensive pathways to detoxify and eliminate excess ROS and protect cells from their detrimental effects (Tavares-Sánchez et al. 2004). This stressresponse include, among others, increased activity of antioxidant enzymes as Catalase (CAT) and Glutathione S- transferase (GST) to restore the normal redox status (Halliwell \& Gutteridge 1999; Borgeraas \& Hessen 2000; Souza et al. 2012). Both enzymes are used as stress status biomarkers when organisms are under different stressors (Livingstone 2003; Kim et al. 2009). Acetylcholinesterase (AChE) activity is a classic biomarker that has been used to monitor toxic contaminants (Forget et al. 2003). More recently it has been shown that AChE is also altered under ultraviolet radiation stress (Souza et al. 2010). AChE hydrolyze Acetylcholine (ACh), a primary neurotransmitter in the sensory and neuromuscular systems in most species (Forget et al. 2003). Regulated AChE activity is 
vital to preserve normal muscular functioning. A decrease in this crucial enzyme results in a build-up of ACh causing a continuous and excessive stimulation of the nervemuscle fibres, and consequently, changes in movement capabilities (Forget et al. 2003).

Thus, in order to analyze the stress caused by ash, we evaluate GST and AChE activities under volcanic ash exposure in Daphnia commutata. The organisms used in the experiments come from a clonal population of $D$. commutata started from a single female isolated from the population of Lake Mascardi (Nahuel Huapi National Park, Patagonia, Argentina). The clone was maintained under laboratory conditions since 2007 at $15^{\circ} \mathrm{C}$ and $85 \mu \mathrm{mol}$ photons. $\mathrm{m}^{-2} . \mathrm{s}^{-1}$ with a 14:10 light: dark photoperiod fed with $1.2 \mathrm{mg} \mathrm{C} / \mathrm{L}$ of C. reinhardtii (Balseiro et al. 2008). In the same laboratory conditions, we exposed 12 individuals of D. commutata to 0 (control) or 5 $\mathrm{mg}$ ash/L (treatment) in five replicates.

Results showed that the treatment with $5 \mathrm{mg}$ L-1 of volcanic ash caused an increase in GST activity, indicating that volcanic ash induced oxidative stress (Figure 2A). Enhanced antioxidant and detoxifying activities had been linked with exposure to several toxic compounds as pesticides, heavy metal (i.e., cadmium, cooper and aluminum), carcinogens and even some organic matter compounds (Barata et al. 2005; Hayes et al. 2005; Souza et al. 2012). However, a report highlighted the lack of toxic compounds in volcanic ash generated during Puyehue-Cordón Caulle eruption (Caneiro et al. 2011). Therefore, we can speculate that others mechanisms are involve in the increased enzyme activity observed, as for example, the crystalline silica (Fubini \& Hubbard 2003) and the iron-induced hydroxyl radicals generation by suspended volcanic ash (Horwell et al. 2003; Horwell et al. 2007). This process occurs mainly in iron-rich ash with low weathering level. Accordingly, studies on Puyehue-Cordón Caulle ash composition reported higher iron concentration than expected (Caneiro et al. 2011). Concurrent with the increase in oxidative stress, ash significantly decreased AChE activity (Figure 2B). Strikingly, a similar effect of increased oxidative stress and a decrease in AChE activity has been shown for ultraviolet radiation, suggesting that $\mathrm{AChE}$ decreases when cell cannot compensate for the increase in ROS (Souza et al. 2010). The decrease in AChE activity would imply that planktonic organisms may be affected in their motility as an indirect consequence of the suspended volcanic ash.

\section{ORGANISMIC-POPULATION SCALE}

The analysis at the organismic level was carried out through life table experiment with the cladoceran Daphnia commutata in an ash concentration gradient (0-8 mg L-1) during 35 days (Wolinski et al. 2013). Laboratory conditions were the same as the above mentioned subcellular scale experiments, but

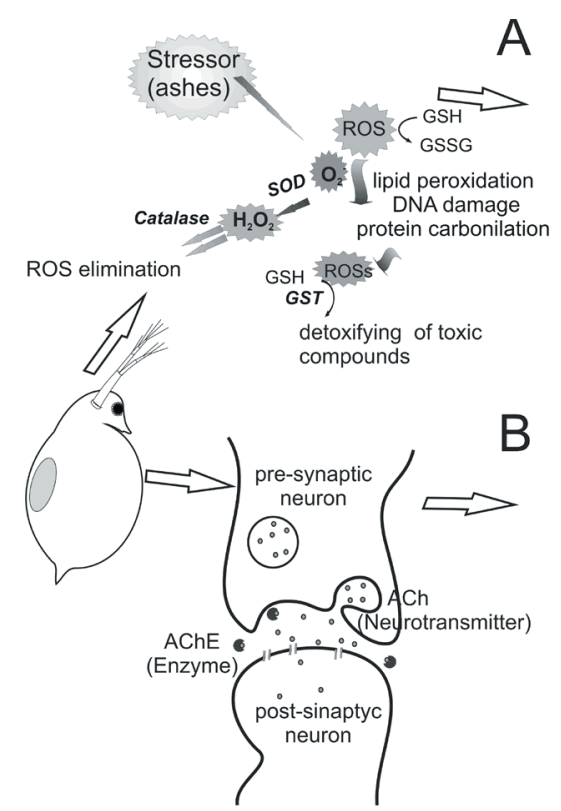

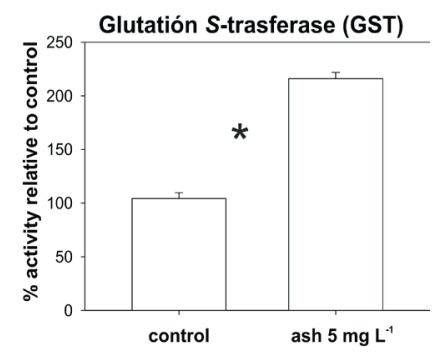

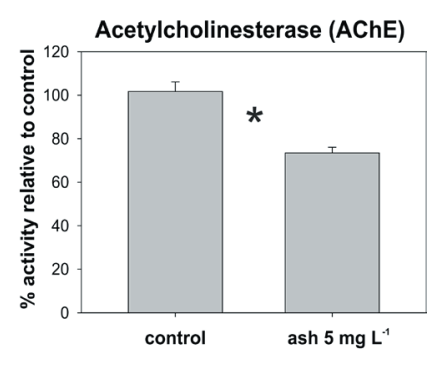

Figure 2. Subcellular level. Enzymes analyzed and their functions and the results of assays with Daphnia commutata exposed to volcanic ash. Results are mean \pm S.E. of five replicates. (A) increase in GST activity and (B) decrease in AChE activity due to ash. *=significant differences in enzyme responses.

Figura2.Nivelsubcelular.Esquema mostrando las enzimas estudiadas y sus funciones y los resultados de los experimentos de exposición de Daphnia commutata a las cenizas volcánicas. Los resultados son medias \pm e.s. de 5 réplicas. (A) incremento de la actividad de GST y (B) disminución de la actividad de $\mathrm{AChE}$ en presencia de las cenizas en suspensión. *=diferencias significativas en las respuestas enzimáticas. 
in this case each flask contained four neonates and each treatment group [0 (control), 1, 2, 3, 5 and $8 \mathrm{mg} \mathrm{L}-1]$ was run in 15 replicates. The ash concentrations used in the experiment were similar to those observed in different impacted lakes after the eruption (Figure 1). We analyzed the survival and fecundity per day for each treatment. Ash concentrations over $2 \mathrm{mg} \mathrm{L}-1$ resulted to be detrimental for $D$. commutata population, since both fecundity and survival were negatively affected (Wolinski et al. 2013). The mean life expectancy was significantly diminished with increasing ash concentration (Figure 3). In particular in the treatment with $8 \mathrm{mg} \mathrm{L}-1$ of ash, we observed that $D$. commutata is not

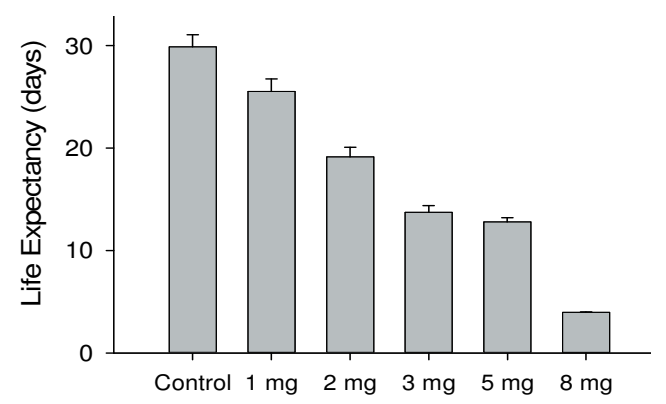

Figure 3. Population level. Life expectancy $\left(\mathrm{e}_{0}\right)$ of Daphnia commutata exposed to increasing concentrations of volcanic ash. Results are mean \pm S.E. of 15 replicates. The relationship $\mathrm{e}_{0}$-ash concentration $r^{2}=0.93$.

Figura 3. Nivel poblacional. Expectativa media de vida $\left(\mathrm{e}_{0}\right)$ de Daphnia commutata expuestos a concentraciones crecientes de cenizas. Los resultados son medias \pm E.S. de 15 réplicas. La relación $\mathrm{e}_{0}$-concentración de cenizas $r^{2}=0.93$.

able to persist, as all individuals died before reaching reproductive age.

As a result of this experiment we were able to conclude that the population parameters of cladocerans are negatively affected by the ash concentrations found in the affected lakes. On one hand, we confirmed through photographs that Daphnia cannot avoid the ingestion of ash together with the food, which causes Daphnias' gut to be clogged by ash (see Wolinski et al. 2013). This leads to an assimilation deficiency due to the presence of inorganic particles. On the other hand, due to the crystalline structure and the sharp edges of the ash, ash caused an abrasion of the gut walls (Wolinski et al. 2013).

\section{ECOSYSTEM LEVEL}

Data from field sampling comes from previous studies (Balseiro et al. 2007) and our own data- set carried out during and after the eruption every 15 days during summers 2011-2012 and 2012-2013 (December to March) (Wolinski et al. 2013; Modenutti et al. 2013a). The data comes from three affected lakes: Lakes Espejo, Correntoso and Nahuel Huapi (Figure 1) (see also Modenutti et al. 2013a). All samples were obtained in replicates from a central sampling point located at the deepest part of each lake basin. Water and phytoplankton samples of 12 $\mathrm{L}$ were obtained with a Schindler-Patalas trap from depths of $0,10,20,30$ and $45 \mathrm{~m}$, while zooplankton were sampled with vertical tows from $50 \mathrm{~m}$ to the surface with a Bongo net (55 $\mu \mathrm{m}$ mesh size) with a closing mechanism [for details see Wolinski et al. (2013); Modenutti et al. (2013a)].

After the eruption event, we recorded in the affected lakes Espejo, Correntoso and Nahuel Huapi (Figure 1) an increase in total suspended solid from $<1 \mathrm{mg} \mathrm{L}-1$ (before the eruption) to $8 \mathrm{mg}$ L-1 (after the event). Concurrently, we recorded an increase in the attenuation light coefficient $\left(\mathrm{K}_{\mathrm{d}}\right)$, an increase in phytoplankton abundances and a upper location of the deep chlorophyll maxima (Modenutti et al. 2013a, 2013b). On the contrary, 6 months after the eruption event the abundance of crustacean zooplankton decreased and the community structure changed, mainly due to the disappearance of cladocerans (Figure 4). Food shortage or changes in phytoplankton cell size could not be the cause of the failure of cladoceran populations as phytoplankton biomass and cell abundance increased after the eruption (Figure 4A and 4B). This phytoplankton increase was mainly a consequence of shading by ash that increase $\mathrm{K}_{\mathrm{d}}$ reducing phytoplankton photoinhibition, combined with nutrient addition (mainly ash-borne phosphorus) (Modenutti et al. 2013a). Therefore, it is especially interesting that although the producer level increased in biomass, it was not mirrored in the next trophic level, the herbivorous zooplankton (Figure 4C). Copepods did not increase and cladocerans disappeared in the summer following the eruption, when we did not record any offspring (Wolinski et al. 2013). It is evident that the presence of ash caused, as explained before, a high cellular stress and a decrease in assimilation that led finally to a drop in survival and fecundity at the herbivorous filter-feeding level. It is worth mention that the total suspended solids in the lakes reached concentrations higher than $8 \mathrm{mg}$ L-1, a concentration that was demonstrated 


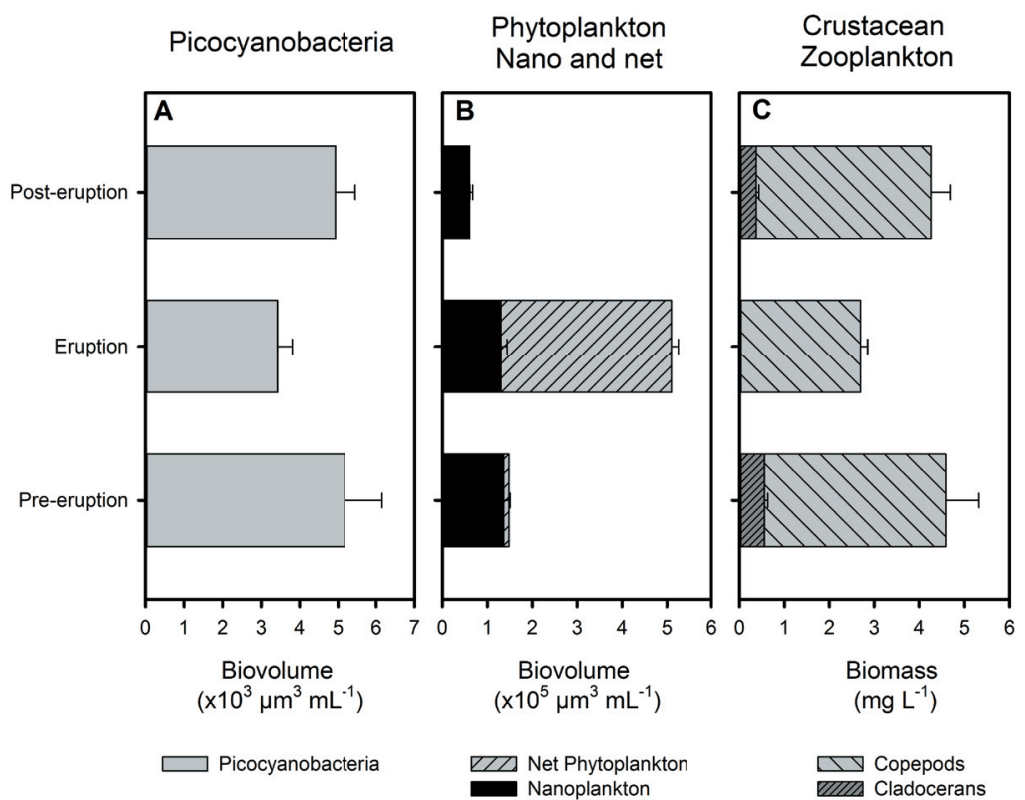

Figure 4. Ecosystem level. (A) Picoplankton (picocyanobacteria) biovolume $\left(10^{3} \mu^{3} / \mathrm{mL}\right)$, (B) Nanoplankton and net phytoplankton biovolume $\left(10^{5} \mu \mathrm{m}^{3} / \mathrm{mL}\right)$, and (C) crustacean zooplankton biomass $(\mu \mathrm{g} / \mathrm{L})$ in the affected lakes (Espejo, Correntoso and Nahuel Huapi) previous years (pre-eruption), in the summer 2011-2012 (eruption) and in summer 2013 (post-eruption). Zooplankton samples are vertical tows from 45 to 0 $\mathrm{m}$. Data are in average \pm S.E. (summer samples: DecemberMarch twice a month: data 10 samples previous; 8 samples during and 8 samples after the event). See details of sampling in the text and in Modenutti et al. (2013) and Wolinski et al. (2013).

Figura 4. Nivel Ecosistémico: (A) Biovolumen de picoplancton (picocianobacterias) $\left(10^{3} \mu \mathrm{m}^{3} / \mathrm{mL}\right.$ ), (B) biovolumen de nanoplancton y fitoplancton de red $\left(10^{5} \mu \mathrm{m}^{3} / \mathrm{mL}\right)$, y $(\mathrm{C})$ biomasa $(\mathrm{\mu g} / \mathrm{L})$ de crustáceos planctónicos (cladóceros y copépodos) en los lagos afectados (Espejo, Correntoso y Nahuel Huapi) en años anteriores a la erupción (pre-eruption), en el verano 2011-2012 (eruption) y en el verano 2013 (post-eruption). Ver detalles en leyenda en inglés.

to be lethal for cladocerans. Suspended ash concentrations as low as $2-3 \mathrm{mg} \mathrm{L}-1$, frequently observed in the affected lakes, were sufficient to reduce both survival and fecundity in the laboratory studies (Wolinski et al. 2013). Equivalent reductions in natural populations would mean that populations under these conditions may not be able to compensate for other mortality sources, such as predation. Hence, these populations might not be able to maintain themselves, thus being strongly reduced even to being not detectable in the lakes, as in the summer following the eruption. Regardless of the better food condition, as they are not able to discriminate between ash and food, filtering zooplankton was strongly diminished. However, copepods seemed to suffer less due to their ability to select for motile cells (Balseiro et al. 2001) and so avoid ingesting ash. The partial reduction observed of this herbivorous trophic level would, in turn, affect higher trophic levels like fish larvae feeding mainly on cladocerans [e.g., Galaxias maculatus, (Modenutti et al. 1993)]. Data from other eruptions in Alaska and Russia indicate that sockeye salmon captures were negatively affected due to a decrease in their resources (Eicher \& Rounsefell 1957; Kurenkov 1966).

In the following summer (January-February 2013), 18 months after the eruption, we observed a recovery of the cladoceran populations (Figure 4C) that was related with the decrease of total suspended solids (ash) in the lakes. This suggests that the recovery of this filter-feeding trophic level is relatively fast and matches previous data from Mount St. Helens eruption (Edmondson \& Litt 1984) were the recovery of zooplankton occurred within the period of one to three years. Hence, immediately after the eruption, it can be expected that cladocerans will disappear, and as we observed, as the ash particles settle and the ash concentration decreases, filter-feeding populations will recover. When lakes return to their original transparency, cladoceran populations recover their historical abundances.

\section{CONCLUSIONS}

We presented a synthesis showing that volcanic eruptions affected pelagic microcrustaceans at different scales. At the subcellular scale the exposition to ash affect the performance because organisms must derive energy to compensate for cellular damage. At the organismic level, the ash ingestion by filter feeding zooplankton has direct effects reducing survival and fecundity. The net result of these changes caused a decrease in the grazer level. At the ecosystem level, the eruption changed the light-nutrient ratio in the water column, reducing the photoinhibition on producers by decreasing light and 
increasing phosphorus, causing an increase in the producer level. Therefore volcanic eruption caused a mismatch in the trophic food web with an increase of the producers and a decrease of the herbivores. Finally, the recovery of the pre-eruption initial condition was observed to be relatively fast lasting one to three years.

Acknowledgements: We thank Agencia Nacional de Promoción Científica y Tecnológica (PICT 2011-2240), (PICT 2012-1168), (PICT 2012-0929), National Geographic Society Grant NGS9005-11, CONICET and Universidad Nacional del Comahue.

\section{REFERENCES}

Balseiro, EG \& BE Modenutti. 1990. Zooplankton dynamics of Lake Escondido (Rio Negro, Argentina), with special reference to a population of Boeckella gracilipes (Copepoda, Calanoida). Int. Rev. gesamten Hydrobiol., 75:475-491.

Balseiro, EG; BE Modenutti \& CP Queimaliños. 2001. Feeding of Boeckella gracilipes (Copepoda, Calanoida) on ciliates and phytoflagellates in an ultraoligotrophic Andean lake. J. Plankton Res., 23:849-857.

Balseiro, EG; BE Modenutti; C Queimaliños \& M Reissig. 2007. Daphnia distribution in Andean Patagonian lakes: effect of low food quality and fish predation. Aquat. Ecol., 41:599-609.

Balseiro, EG; MS Souza; BE Modenutti \& M Reissig. 2008. Living in transparent lakes: Low food P:C ratio decreases antioxidant response to ultraviolet radiation in Daphnia. Limnol. Oceanogr., 53:2383-2390.

Barata, C; I Varo; JC Navarro; S Arun \& C Porte. 2005. Antioxidant enzyme activities and lipid peroxidation in the freshwater cladoceran Daphnia magna exposed to redox cycling compounds. Comp. Biochem. Physiol. C: Toxicol. Pharmacol., 140:175-186.

BoERSMA, M \& J ViJverberg. 1996. Food effects on life history traits and seasonal dynamics of Ceriodaphnia pulchella. Freshw. Biol., 35:25-34.

BORGERAAS, J \& DO HESSEN. 2000. UV-B induced mortality and antioxidant enzyme activities in Daphnia magna at different oxygen concentrations and temperatures. J. Plankton Res., 22:1167-1183.

Brett, MT; DC Müller-Navarra \& SK Park. 2000. Empirical analysis of the effect of phosphorus limitation on algal food quality for freshwater zooplankton. Limnol. Oceanogr., 45:1564-1575.

Buteler, M; T Stadler; GP López García; MS Lassa; D Trombotto Liaudat; et al. 2011. Propiedades insecticidas de la ceniza del complejo volcánico Puyehue-Cordón Caulle y su posible impacto ambiental. Rev. Soc. ent. Arg., 70:149-156.

Caneiro, A; L Mogni; A Serquis; C Cotaro; D Wilberger; ET AL. 2011. Análisis de cenizas volcánicas del Cordón Caulle (complejo volcánico Puyehue-Cordón Caulle). Comisión Nacional de Energía Atómica.

Carpenter, SR; PR Leavitt; JJ Elser \& MM Elser. 1988. Chlorophyll budgets: response to food web manipulation. Biogeochemistry, 6:79-90.

CARPenter, SR; JF Kitchell; KL Cottingham; DE Schindler; DL Christensen; ET AL. 1996. Chlorophyll variability, nutrient input, and grazing: Evidence from whole-lake experiments. Ecology, 77:725-735.

Carpenter, SR; JJ Cole; JR Hodgson; JF Kitchell; ML PACE; ET AL. 2001. Trophic cascades, nutrients, and lake productivity: whole-lake experiments Ecol. Monogr., 71:163-186.

DeMotT, WR. 1982. Feeding selectivities and relative ingestion rates of Daphnia and Bosmina. Limnol. Oceanogr., 27:518-527.

DeMotт, WR. 1986. The role of taste in food selection by freshwater zooplankton. Oecologia, 69:334-340.

DEMотT, WR. 1989. Optimal foraging theory as a predictor of chemically mediated food detection by suspensionfeeding copepods. Limnol. Oceanogr., 34:140-154.

Durant, Aj; G Villarosa; WI Rose; P Delmelle; AJ Prata; et AL. 2012. Long-range volcanic ash transport and fallout during the 2008 eruption of Chaitén volcano, Chile. Phys. Chem. Earth, 45-46:50-64.

EDMONDSON, W \& AH LiTT. 1984. Mount St Helens ash in lakes in the lower Grand Coulee, Washington State. Verh. Internat. Verein. Limnol., 22:510-512.

EICHER, GJJ \& GA RounsefeLL. 1957. Effects of lake fertilization by volcanic activity on abundance of salmon. Limnol. Oceanogr., 2:70-76.

Faithfull, CL; M Huss; T VRede \& AK Bergström. 2011. Bottom-up carbon subsidies and top-down predation pressure interact to affect aquatic food web structure. Oikos, 120:311-320.

Forget, J; B Beliaeff \& G BocqueneÌ. 2003. Acetylcholinesterase activity in copepods (Tigriopus brevicornis) from the Vilaine River estuary, France, as a biomarker of neurotoxic contaminants. Aquat. Toxicol., 62:195-204.

Fubini, B \& A HubBard. 2003. Reactive oxygen species (ROS) and reactive nitrogen species (RNS) generation by silica in inflammation and fibrosis. Free Radical Biol. Med., 34:1507-1516.

GelLer, W \& H MülLER. 1981. The filtration apparatus of Cladocera: filter mesh-sizes and their implications on food selectivity. Oecologia, 49:316-321.

GLIwicz, ZM. 1986a. Suspended clay concentration controlled by filter-feeding zooplankton in a tropical reservoir. Nature, 323:330-332.

GLIwICZ, ZM. 1986b. Predation and the evolution of vertical migration in zooplankton. Nature, 320:746-748.

Halliwell, B \& JM GutTeridge. 1999. Free radicals in biology and medicine. Oxford university press Oxford.

HaYes, JD; JU Flanagan \& IR Jowsey. 2005. Glutathione Transferases. Annu. Rev. Pharmacol. Toxicol., 45:51-88.

Holling, CS. 1973. Resilience and stability of ecological systems. Annu. Rev. Ecol. Syst., 4:1-23.

Horwell, CJ; RSJ SParks; TS BRewer; EW Llewellin \& BJ WILLIAMSON. 2003. Characterization of respirable volcanic ash from the Soufrière Hills volcano, Montserrat, with implications for human health hazards. Bull. Volcanol., 65:346-362.

Horwell, CJ; I Fenoglio \& B Fubini. 2007. Iron-induced hydroxyl radical generation from basaltic volcanic ash. Earth Planet. Sci. Lett., 261:662-669.

Inbar, M; H Ostera; C Parica; M Remesal \& F SAlani. 1995. Environmental assessment of 1991 Hudson volcano eruption ashfall effects on southern Patagonia region, Argentina. Environ. Geol., 25:119-125.

JÜRGENS, K. 1994. Impact of Daphnia on planktonic microbial food webs- a review. Mar. Microb. Food Webs, 
8:295-324.

KIM, J; Y PARK \& K CHOI. 2009. Phototoxicity and oxidative stress responses in Daphnia magna under exposure to sulfathiazole and environmental level ultraviolet B irradiation. Aquat. Toxicol., 91:87-94.

KIRK, KL \& JJ Gilbert. 1990. Suspended clay and the population dynamics of planktonic rotifers and cladocerans. Ecology, 71:1741-1755.

Klüser, L; T Erbertseder \& J Meyer-Arnek. 2013. Observation of volcanic ash from Puyehue-Cordón Caulle with IASI. Atmos. Meas. Tech. Dis., 6:35-46.

KURENKOV,I. 1966. The influence of volcanic ashfall on biological processes in a lake. Limnol. Oceanogr., 11:426-429.

LAMPERT, W. 1987. Feedig and nutrition in Daphnia. Mem. Ist. Ital. Idrobiol., 45:143-192.

LARSON, DW. 2011. Science after the volcano blew: Research near Mount St. Helens proceeded despite bureaucratic hurdles, limited funding and an extremely hazardous environment. Am. Sci., 98:324-333.

LINDENMAYER, DB; GE LIKENS \& JF FRANKLIN. 2010. Rapid responses to facilitate ecological discoveries from major disturbances. Front. Ecol. Environ., 8:527-532.

Livingstone, DM. 2003. Impact of secular climate change on the thermal structure of a large temperate central European lake. Clim. Chang., 57:205-225.

LYNCH, M. 1989. The life history consequences of resource depression in Daphnia pulex. Ecology, 70:246-256.

Matveev, VF \& EG Balseiro. 1990. Contrasting responses of two cladocerans to changes in the nutritional value of nannoplankton. Freshw. Biol., 23:197-204.

McCABE, GD \& WJ O'BRIEN. 1983. The effects of suspended silt on feeding and reproduction of Daphnia pulex. Am. Midl. Nat., 110:324-337.

McQueEn, DJ; MRS Johannes; JR Post; TJ Stewart \& DRS LEAN. 1989. Bottom-up and top-down impacts on freshwater pelagic community structure. Ecol. Monogr., 59:289-309.

Modenutti, BE; EG Balseiro \& PM Cervellini. 1993. Effect of selective feeding of Galaxias maculatus (Salmoniforme, Galaxiidae) on zooplankton of a South Andes lake. Aquat. Sci., 55:65-75.

Modenutti, BE; R Albariño; M Bastidas Navarro; V Díaz Villanueva; MS Souza; ET AL. 2010. Structure and dynamic of food webs in Andean North Patagonian freshwater systems: organic matter, light and nutrient relationships. Ecología Austral, 20:95-114.

Modenutti, BE; EG Balseiro; JJ Elser; M Bastidas NAVARro; F CUASSOLO; ET AL. 2013a. Effect of volcanic eruption on nutrients, light, and phytoplankton in oligotrophic lakes. Limnol. Oceanogr., 58:1165-1175.

Modenutti, BE; EG Balseiro; M Bastidas Navarro; C LASPOUMADERES; MS SOUZA; ET AL. 2013b. Environmental changes affecting light climate in oligotrophic mountain lakes: The deep chlorophyll maxima as a sensitive variable. Aquat. Sci., 75:361-371.

SCHEFFER, M \& SR CARPENTER. 2003. Catastrophic regime shifts in ecosystems: linking theory to observation. Trends Ecol. Evol., 18:648-656.

Serra-Olabuenaga, I. 2013. Respuestas celulares de zoopláncteres frente a estresores ambientales. Trabajo Final de Licenciatura, Universidad Nacional del Comahue.

Siebeck, O; T Vail; CE Williamson; R Vetter; D Hessen; ET AL. 1994. Impact of UV-B radiation on zooplankton and fish in pelagic freshwater ecosystems. Archiv Hydrobiol. Beih. Ergeb. Limnol., 43:101-104.

SINGER, BS; BR JICHA; MA HARPER; JA NARANIO; LE LARA; ET AL. 2008. Eruptive history, geochronology, and magmatic evolution of the Puyehue-Cordón Caulle volcanic complex, Chile. Geol. Soc. Am. Bull., 120:599-618.

Souza, MS; EG Balseiro; C LAspoumaderes \& BE ModenutTi. 2010. Effect of ultraviolet radiation on Acetylcholinesterase activity in freshwater copepods. Photochem. Photobiol., 86:367-373.

SOUZA, MS; LA HANSSON; S HYLANDER; BE MODENUTTI \& EG BALSEIRO. 2012. Rapid enzymatic response to compensate UV radiation in copepods. PLoS One, 7:e32046.

STERNER, RW. 1989. The role of grazers in phytoplankton succession. Pp. 107-170 in: Sommer, U (ed.). Plankton ecology: succession in plankton communities. SpringerVerlag.

TARbuCK, EJ; FK Lutgens \& AM Rubio. 1999. Ciencias de la Tierra: Una introducción a la geología física. PrenticeHall.

TAVAres-SÁnchez,OL; GA Gómez-Anduro; X Felipe-Ortega; MA IsLAs-OsunA; RR Sotelo-Mundo; ET AL. 2004. Catalase from the white shrimp Penaeus (Litopenaeus) vannamei: Molecular cloning and protein detection. Comp. Biochem. Physiol. B, 138:331-337.

VANNI, MJ. 1987. Indirect effect of predators on agestructure prey populations: planktivorous fish and zooplankton. Pp. 149-160 in: Kerfoot, WC \& A Sih (eds.). Predation: Direct and indirect impacts on Aquatic Communities. Univ. Press of New England.

Villarosa, G; V Outes; A Hajduk; EC Montero; D Sellés; ET AL. 2006. Explosive volcanism during the Holocene in the Upper Limay River Basin: The effects of ashfalls on human societies, Northern Patagonia, Argentina. Quat. Int., 158:44-57.

Walker, B \& JA Meyers. 2004. Thresholds in ecological and social-ecological systems: a developing database. Ecol. Soc., 9:3.

Wolinski, L; C Laspoumaderes; M Bastidas Navarro; BE Modenutti \& EG Balseiro. 2013. The susceptibility of cladocerans in North Andean Patagonian lakes to volcanic ashes. Freshw. Biol., 58:1878-1888. 